Małgorzata Michel

Uniwersytet Jagielloński

E-MAIL: malgorzata.michel@uj.edu.pl ORCID: oooo-0oo2-2999-5270

\title{
Nad zalew bym sobie pojechał
}

\begin{abstract}
Dr hab. Małgorzata Michel, prof. UJ pracuje w Instytucie Pedagogiki UJ, a jej zainteresowania badawcze lokują się w problematyce lokalnych systemów profilaktyki i resocjalizacji, badania aktywności dzieci na ulicy i członków gangów młodzieżowych, w tym dewiacyjnych grup pseudokibicowskich w kontekście urban studies. Prezentowany tekst jest efektem udziału autorki w warsztatach pisania o pamięci miasta i o historiach osobistych, prowadzonych przez Mikołaja Grydberga w latach 2019-2020. Autorka postanowiła połączyć bycie badaczką jakościową osadzoną w etnometodologii oraz zdobyte na warsztacie umiejętności pisarskie. Tekst jest efektem procesu rozpoczynającego się przeprowadzeniem wywiadu z nastoletnim pseudokibicem, byłym członkiem gangu ulicznego. W efekcie autorka pokazuje jeden ze sposobów prezentacji danych jakościowych, który przybiera formę reportażu.
\end{abstract}

SŁOWA KLUCZOWE: studia miejskie, badania jakościowe, reportaż

Są takie rejony na mieście, gdzie mogę sobie swobodnie chodzić. Znam je. Jak muszę wyjść z domu na przykład o godzinie dwunastej, to o godzinie dziesiątej-jedenastej sprawdzam sobie jakąś normalną drogę, najszybszą. Czasem ryzykuję, a czasem nie. Czasem mi się opłaca, czasem nie. Wolę dłużej wracać do domu niż wylądować w szpitalu. Sprawdzam linię. Jak chcę jechać na stadion, załóżmy, że tam 502 jedzie. To sprawdzam, którędy jedzie i sobie jadę, nie? No po prostu przez przystanki i tereny. To zależy. Jak potrzebuję gdzieś się dostać, a nie mogę, dzwonię po kumpla i jedziemy autem. $Z$ domu najczęściej chodzę z buta, bo mam wszędzie blisko. To znaczy to nie jest mój prawdziwy dom. Mieszkam w ośrodku i na grupie usamodzielnienia w placówce. Na grupie w weekend. Mam też dom na jednym osiedlu. Nie przebywam tam za często. Nie lubię tam przebywać. Czasami parę godzin posiedzę. Więcej czasu w życiu przesiedziałem na osiedlu niż w tym domu. Jak byłem młodszy oczywiście. Tak, żebym posiedział dzień i noc, to może dziesięć razy byłem? Tak mniej więcej. Nie lubię atmosfery, która tam panuje.

Dużo jest takich osób, które, jakbym zadzwonił, to mi pomogą. W różnych sprawach. Takich codziennych sprawach, akcjach na przykład. Nie mówię konkretnie, po prostu w różnych. Niezwykłe jest to, że nie ma tak, 
że od swoich się odwrócą. Zawsze mi ktoś pomoże. Zadzwonię, to trzy auta są pod blokiem. Jeśli chodzi o nastukanie kogoś, to dzwonię i są. Znajomości się nabywa. Po prostu. Są różne akcje. Idzie ktoś na przykład, nie? Jeśli to jest jakaś grupa na torbach, to jest akcja. Pyta się kogoś o smyczkę z barwami, za kim jest, takie tam. On zwykle pamięta, kto pyta. Idzie taka informacja dalej w miasto. Niektórzy chodzą ze sprzętem, inni nie. W torbach jest gaz pieprzowy, taka 50o- setka na przykład. Maczety, kije bejsbolowe, pałki teleskopowe, młotki, siekiery. Różnie. Co fantazja podpowie. Kraków jest niby duży. Jak się patrzy na to, kto kogo zna, to się robi mały. Wystarczy, że dam zdjęcie na facebooka $z$ twarzą $i$ jeśli jedna osoba mnie zna i jest $w$ takim towarzystwie, to zdjęcie idzie dalej. Jak mnie ktoś zobaczy, wystarczy że biorę udział w jednej akcji, nazwisko idzie, zdjęcie idzie. Chciałbym nie być tak rozpoznawalny, jak jestem. Przez ludzi na mieście. Chciałbym, aby ludzie nie wiedzieli, jak wyglądam. Byłem na osiedlu jedną z ważniejszych osób. Jak coś się działo, pierwszy wiedziałem. Jak coś wpadło w ręce, przekazywałem dalej. Chodzi o skrojony sprzęt, barwy. Bawię się nożykiem? Nieeee. To jest taka duża obcinarka. Zwykły kibic wchodzi na mecz i wychodzi. Wychodzi i wspiera swoją drużynę. Tutaj o inne rzeczy chodzi. To nie jest wspieranie swojej drużyny i zagrzewanie jej do walki. Tutaj chodzi o coś innego. Tereny i narkotyki. Bieganie za kibicami innego klubu, krojenie barw. Ogólnie lanie się po mordach z nimi. Barwy i szaliki pali się później na meczu, ale pokazuje się najpierw na facebooku. Ja miałem stronkę. Jedną legalną i jedną nielegalną. Tam wrzucałem zdjęcia skrojonych rzeczy. To są takie zdobycze, trofea. Kręcimy filmiki jak kogoś kroimy. Idzie w Internet. Z twarzami.

W sumie to czego mam się bać? Trzy czwarte $\mathrm{z}$ nich to $\mathrm{w}$ grupie i ze sprzętem są odważni. Na pięści to już nie. Nosiłem ze sobą sprzęt. Na początku. Podszedłem raz do takiego jednego. Dwóch ich było. Ja byłem sam. Jeden miał saszetkę w pasie, odwróconą tyłem, więc nie widziałem. Zapytałem: „za kim jesteś?" On mówi że Wisła. No dobra. Dwóch, to sobie poradzę- pomyślałem. Powiedziałem im, aby wyszli przed sklep. Bo to było w sklepie. No to wyszliśmy, a on wyciąga butlę. Znaczy gaz pieprzowy. No to mówię: „kurwa”. Bo to już ciężej jest. No i rura na osiedle. Oni nie znali terenu. To osiedle z mocą. Skrzyknąłem chłopaków i dostali po mordzie. To wtedy zacząłem chodzić z maczetą. Miałem może czternaście lat? Różnie się zaczyna. Tak zwykle w wieku trzynastu, może czternastu lat. Innym razem podeszło trzech. Pytają: „za kim jesteś?” no to wyciągnąłem sprzęt. Powiedzieli: „no ale bez sprzętu" i odeszli. Czego mam się bać? Jeden był naćpany. Biłem go długo. Wygrałem. On przeżył. Zaczyna się tak, że jak małolaty sobie biegają, to się ich zaczepia. Zwykle pada pytanie: „za kim jesteś?”. Są młodsi i starsi. 
Starsi to jeszcze inna bajka. Oni mają tak po dwadzieścia parę lat. Nie wtrącają się. No, ale jak robimy burdel na osiedlu, to reagują. Ma być spokój. Jest grupa i zasady. Zasada Vegas - wiadomo. Cztery ściany i nic nie wychodzi na zewnątrz. Jak jest kret, to się pucuje i zostaje wyautowany. Dostaje przekopę i tyle. Chłopaków się sprawdza. Bierze się na akcję i sprawdza, czy się boi. Zawsze jest sprawdzanie. Jest grupa to są zasady. Wisła bierze młodych do piwnicy i uczy ciąć maczetą. U nas tak nie jest. Nam nie wolno palić papierosów do piętnastu, szesnastu lat. Tak mniej więcej. Starsi pilnują. Dziewczyny tylko chcą z nami przebywać, one nie chodzą na akcje. Chodzą z nami na melanże. Lubią pokazywać się w grupie. Są tak jakby pasowane do grupy, dostają po prostu paskami. Jak jest dwudziestu chłopaków na przykład, to dwudziestu je bije tym paskiem.

W sumie to błędne koło. Głupota. Teraz zaczynam od nowa. Chcę skończyć szkolę, znaleźć jakąś pracę i wyprowadzić się. Żeby było normalnie. Za małolacika miałem normalne życie. Od rana do wieczora w piłkę grałem i na komputerze. Wychodziłem z domu od rana do wieczora, Siedziałem ze znajomymi. Lepiej było. $\mathrm{Z}$ tego domu $\mathrm{z}$ rodziną zastępczą. O tym mówię. Tylko, że ja zacząłem siedzieć na osiedlu z tymi ludźmi. Teraz zmądrzałem. Chcę założyć rodzinę i wyjść z dzieckiem przed blok normalnie. Nie, żeby nam się coś stało. Nie chcę skończyć w grobie w wieku dwudziestu pięciu lat. Teraz to już emerytura jeśli o mnie chodzi. Mam siedemnaście lat. Przeginałem. Teraz jestem w ośrodku. Tamci rodzice mnie już nie chcieli. Tego kolegę w czerwcu nie ja pociąłem. Był na przepustce. Jest przypał, bo pokroili go maczetą. Przeżył. I teraz jest na mnie. A Miłosza nie znałem. Uśmiecham się? Zawsze się uśmiecham. Wspomnienia nie są radosne. Po prostu uśmiecham się. Czy Miłosz był zaangażowany w działania gangu? Nie wiem. Kibicował Cracovii. Tyle.

Tęsknię za normalnym życiem. Nad zalew bym na przykład pojechał. Ale nie mogę. Bo mnie zabiją kibice przeciwnej drużyny. Teraz mieszkam w ośrodku młodzieżowym. Na weekendy w mieszkaniu usamodzielnienia. Tutaj spędzam większość czasu. To nie jest mój prawdziwy dom. Gotujemy sami. Wszystkie posiłki oprócz śniadania. Są dyżury. To wszystko. Jak będę mieszkał sam, będę miał po prostu więcej obowiązków. Będę musiał wszystko robić sam. Tyle.

Nie mam domu. W sumie. Przebywam w różnych miejscach. Najpierw byłem w domu dziecka. Matka, gdybym ją spotkał, dostała by ode mnie cegłą. Jest pijaczką. To przez nią ojciec się zabił. Tak mi wszyscy mówili tam, skąd jestem. Nie z Krakowa. Nie zdążyłem poznać ojca, bo byłem mały. Nie wiem, jak wyglądał. Nie znałem go. Nawet nie mam jak za nim tęsknić. 


\section{I would go to the bay}

Malgorzata Michel, $\mathrm{PhD}$ at Jagiellonian University works at the Institute of Education. Her research focuses mainly on local prevention and rehabilitation systems, studying activity of the „street children" afiliating with youth gang activity and deviant hooligan groups in the context of urban studies. The presented text is the outcome of taking part in Mikolaj Grynberg's workshops focusing on writing about city memory and personal stories in years 2019-2020. Malgorzata Michel combines being a qualitative researcher set in ethnomethodology and writing skills achieved on later mentioned workshops. Her text is an outcome of a process starting with and interview with a teenage hooligan, ex street gang member. Finally, the author showcases a way to present qualitative data in form of a reportage.

KEY WORDS: urban studies, qualitative researchs, reportage. 